\title{
Cendawan Patogen pada Beberapa Varietas Jagung di Kabupaten Timor Tengah Utara
}

Albertus Hausufa ${ }^{\mathrm{a}}$, dan Aloysius Rusae ${ }^{\mathrm{b}}$

${ }^{a}$ Fakultas Pertanian, Universitas Timor, Kefamenanu, TTU - NTT, Indonesia.

${ }^{b}$ Fakultas Pertanian, Universitas Timor, Kefamenanu, TTU - NTT, Indonesia.

\section{Article Info}

Article history:

Received 17 Juli 2017

Received in revised form 6 Maret 2018

\section{Keywords:}

Fusarium sp

Aspergillus $\mathrm{sp}$

Benih Jagung
Accepted 4 April 2018

\section{Abstrak}

Jagung merupakan bahan pangan yang penting karena jagung merupakan sumber karbohidrat kedua setelah beras. Benih salah satu komponen penting dalam keberhasilan peningkatan produksi pertanian. Penelitian ini bertujuan untuk mengetahui jenis cendawan yang berasosiasi pada benih jagung, dilakukan bulan April sampai bulan Mei 2017 di laboratorium Fakultas Pertanian Universitas Timor. Penelitian menggunakan Rancangan Acak Lengkap (RAL) Faktorial. Identifikasi patogen dilakukan dengan karakterisasi morfologi, selain itu dilakukan pengujian daya berkecambah benih dan potensi tumbuh maksimum dengan metode UKDdp. Benih yang digunakan adalah varietas Lokal Putih kecil, varietas lokal putih besar dan hibrida, berasal dari beberapa daerah berdasarkan ketinggian tempat yakni Eban 1000 mdpl, Mamsena 400-800 mdpl, Wini 100-200 mdpl. Hasil identifikasi didapatkan dua genus yaitu Aspergillus sp1, Aspergillus sp2, Aspergillus sp3 dan Fusarium sp, serangan cendawan Aspergillus sp1 tertinggi pada varietas lokal kecil 7,78\% dan ketinggian tempat T2 (Wini), Fusarium sp tertinggi pada varietas jagung hibrida 40,00\% dan ketinggian tempat tertinggi pada T1 (Eban) 8,67\%. Pengujian daya kecambah benih pada ketiga varietas berkisar antara 16,44\%-26,00\%. @2018 dipublikasikan oleh Savana Cendana.

\section{Pendahuluan}

Jagung (Zea mays L.) merupakan salah satu bahan pangan yang penting karena jagung merupakan sumber karbohidrat kedua setelah beras. Di samping itu, jagung merupakan bahan baku industri dan pakan ternak (Purwono \& Hartono, 2008). Jagung memiliki kandungan karbohidrat 18,7 g, pati 5,7 g, gula $6,26 \mathrm{~g}$, serat pangan $2 \mathrm{~g}$, lemak 1,35 g, protein 3,27 g, jagung memiliki sumbe serat yang sangat baik sehingga sehat untuk sistem pencernaan. Sumber kalori tertinggi dalam kelompok sereal yang rendah gula sehingga baik untuk dikonsumsi sebagai makanan pokok pengganti nasi atau beras terutama pada penderita diabetes dan hipertensi, dan $100 \mathrm{~g}$ jagung mengandung 9,2 g protein. Protein membantu membentuk jaringan otot baru dan meningkatkan kerja se dalam tubuh. Selain itu protein juga meningkatkan sistem kekebalan tubuh.

Jagung di wilayah kabupaten Timor Tengah Utara (TTU) memberikan hasi yang cukup baik dan masih digunakan sebagai bahan makanan pokok bagi masyarakat di sebagian wilayah pedesaan. Hasil penelitian Leki et al., (2016) menunjukkan jagung yang ditanam secara tumpangsapi dengan kacang hijau dapat memberikan hasil 0,9 t/ha berupa pipilan kering, sedangkan hasil penelitian Wonkay \& Taolin, (2016) menunjukkan jagung dapat memberikan hasil $1 \mathrm{t} / \mathrm{ha}$ berupa pipilan kering. Benih merupakan salah satu komponen penting dalam keberhasilan peningkatan produksi pertanian. Penggunaan benih bermutu mampu meningkatkan produksi pertanian dan mengurangi serangan hama dan penyakit di lapangan. Patogen terbawa benih dapat menyebabkan penurunan viabilitas benih, peningkatan kematian bibit, penurunan hasil, peningkatan perkembangan penyakit, perubahan komponen kimia benih, dan ledakan penyakit pada suatu daerah (Agarwal \& Sinclair, 1987).

Salah satu faktor eksternal yang berpengaruh terhadap kualitas benih jagung adalah infeksi cendawan Aspergillus sp, Fusarium sp. cendawan tersebut dominan ditemukan pada benih jagung dalam penyimpanan (Muis et al. 2002). Infeksi awal terjadi pada fase silking di lapang, kemudian terbawa oleh benih ke tempat-tempat penyimpanan (Schutless et al. 2002). Patogen-patogen tersebut kemudian berkembang dan memproduksi mikotoksin, sehingga benih menjadi rusak dan bermutu rendah. Di daerah beriklim tropis, suhu, curah hujan, dan kelembaban yang tinggi serta media penyimpanan tidak memadai, sangat mendukung perkembangan patogen-patogen tersebut untuk berkembang. Infeks kedua patogen tersebut dapat mengakibatkan warna benih berubah, perkecambahan terhambat, dan dapat menyebabkan penyakit di persemaian atau pada tanaman dewasa di lapangan.

Benih yang berkualitas berperan penting dalam menghasilkan tanaman yang memiliki kualitas tinggi dan untuk mendapatkan benih yang bebas dar kontaminasi cendawan patogen maka perlu dilakukan pengujian kesehatan benih. Pentingnya uji kesehatan benih dilakukan karena penyakit yang disebabkan oleh keberadaan cendawan patogen pada benih dapat mengganggu perkecambahan dan pertumbuhan benih dengan demikian merugikan kualitas dan kuantitas hasil. Benih dapat menjadi pengantar, baik hama maupun penyakit ke daerah lain dimana hama dan penyakit itu tidak ada sebelumnya. Pengujian kesehatan benih akan mendeteksi dan dapat mengurangi kontaminasi cendawan patogen pada benih tersebut sehingga dapat mengurangi risiko penurunan hasil. Tujuan dari penelitian ini adalah mengidentifikasi cendawan pathogen pada benih jagung di beberapa tempat di kabupaten TTU.

\section{Metode}

Penelitian dilaksanakan pada bulan April sampai bulan Mei 2017. Pengamatan secara mikroskopis di laboratorium Fakultas Pertanian dan laboratorium Biologi Universitas Timor, Kabupaten TTU. Pengambilan benih berdasarkan ketinggian tempat atau sumber benih yakni beberapa tempat yaitu: Eban dengan ketinggian 1000 mdpl dan Wini dengan ketinggian 100-200 mdp dan Mamsena dengan ketinggian 400-800 mdpl dan selanjutnya akan dilakukan pelaksanaan identifikasi benih di Laboratorium. Tata letak percobaan disusun dengan Rancangan Acak Lengkap (RAL) pola faktorial dengan dua faktor.

Isolasi patogen dilakukan dengan menginkubasi benih jagung pada cawan petri yang telah disterilisasi. Benih ditanam dalam cawan petri berisi media PDA yang sebelumnya telah diberi Chloramphenicol untuk mencegah pertumbuhan bakteri, kemudian pemurnian cendawan yang tumbuh berdasarkan warna koloni. Karakterisasi cendawan patogen dilakukan secara makroskopis dan mikroskopis. Pengamatan secara makroskopis yaitu pengamatan secara langsung melihat ciri khas koloni berupa bentuk, warna dan tepi koloni. Pengamatan secara mikroskopis yaitu pengamatan karakteristik cendawan berupa: Hifa sepert warna, bersekat atau tidak dan pola percabangan. Konidia berupa bentuk, warna dan ukuran. Konidiofor berupa warna, bersekat atau tidak, bercabang atau tidak dan ukuran konidiofor. Pengamatan cendawan patogen sesuai petunjuk Mathur \& Kongsdal, (2003)

Parameter pengujian kesehatan benih menggunakan metode uji kertas digulung didirikan pada plastik (UKDdP) meliputi daya berkecambah (DB) (\%) cendawan dengan menumbuhkan isolat cendawan pada media PDA berdasarkan genus cendawan, diinkubasi selama 4 hari kemudian pengamatan dengan mikroskop. Tujuan menumbuhkan isolat cendawan pada media PDA adalah untuk pengamatan karakter koloni cendawan. Pengamatan kejadian kontaminasi cendawan patogen. Seluruh benih yang diinkubasi dalam cawan petri tersebut menjadi sampel. Kejadian penyakit dapat dihitung dari jumlah benih yang terinfeksi patogen. Pengamatan terhadap kejadian penyakit dilakukan di setiap cawan petri dengan menghitung jumlah benih terinfeksi penyakit berdasarkan jenis patogen. Data hasil pengamatan kemudian dianalisis dengan menggunakan sidik ragam (Anova) RAL faktorial. Rata-rata perlakuan selanjutnya diuji lanjut dengan menggunakan Duncan Multiple Range Test (DMRT) dengan tingkat signifikan 5\% sesuai petunjuk (Gomez \& Gomez, 1984). Analisis data menggunakan program SAS 9.1

\section{Hasil dan Pembahasan \\ 3.1 Daya Kecambah}

Hasil sidik ragam anova menunjukkan bahwa terjadi interaksi antara varietas dan ketinggian tempat. Pengujian daya kecambah tertinggi terdapat pada jagung lokal besar dengan rerata $26,26 \%$ sedangkan daya berkecambah terendah terdapat pada perlakuan jagung lokal kecil dan jagung hibrida. Berdasarkan ketinggian tempat, daya berkecambah tertinggi $28,00 \%$ pada ketinggian tempat $\mathrm{T} 2$ (Wini) sedangkan daya berkecambah terendah pada ketinggian tempat $\mathrm{T} 1$ (Tabel 1.)

Tabel 1. Daya Berkecambah (\%)

\begin{tabular}{lllll}
\hline \multirow{2}{*}{ Varietas Jagung } & \multicolumn{3}{c}{ Ketinggian Tempat } & \multirow{2}{*}{ Rerata } \\
\cline { 2 - 4 } & T1 (Eban) & T2 (Wini) & T3 (Mamsena) & \\
\hline A1 (Lokal Kecil) & 13.33 & 30.67 & 8.00 & $17.33 \mathrm{~b}$ \\
A2 (Lokal Besar) & 29.33 & 14.67 & 36.00 & $26.67 \mathrm{a}$ \\
A3 (Hibrida) & 5.33 & 38.67 & 5.33 & $16.44 \mathrm{~b}$ \\
\hline Rerata & $16.00 \mathrm{~b}$ & $28.00 \mathrm{a}$ & $16.44 \mathrm{c}$ & $(+)$
\end{tabular}

Keterangan: Angka pada baris dan kolom diikuti dengan huruf yang sama tidak berbeda nyata menurut uji Duncan (HSD) $\alpha 5 \%$. (+) = terjadi interaksi antar faktor.

\subsection{Potensi Tumbuh Maksimum}

Hasil sidik ragam Anova menunjukkan bahwa terjadi interaksi antara varietas dan ketinggian tempat, dimana hasil varietas jagung A1 dan A2 berbeda nyata dengan $\mathrm{A} 3$, untuk ketinggian tempat $\mathrm{T} 2$ berbeda nyata dengan $\mathrm{T} 3 \mathrm{dan} \mathrm{T} 1$ (Tabel 2.). Uji viabilitas benih adalah daya hidup benih yang dapat ditunjukkan dalam berbagai fenomena fisiologis maupun biokimia dan salah satu uji laju pertumbuhan benih yang digunakan sebagai parameter ketahanan persaingan benih dilapang produksi (Sadjad, 1994) Pengujian vigor benih dan daya berkecambah benih dapat memberikan petunjuk mutu benih yang baik dalam hal ini kecepatan benih berkecambah normal dan abnormal, demikian pula berdasarkan pengamatan uji daya kecambah benih pada ketiga varietas jagung diantaranya A1 (jagung putih lokal kecil) A2(jagung putih lokal besar)A3(jagung hibrida) pada ketiga varietas jagung ini untuk pengujian daya berkecambah dan potensi tumbuh maksimum (PTM) (\%). Identifikasi karakter morfologi 
tertinggi terdapat pada varietas jagung lokal putih besar A2 sedangkan daya berkecambah terendah terdapat pada varietas jagung lokal putih kecil A1. Sedangkan untuk uji potensi tumbuh maksimum tertinggi pada varietas jagung lokal putih besar A2, dan terendah pada jagung hibrida untuk ketinggian tempat tertinggi pada T2(Wini) terendah pada T3 (Mamsena).

Tabel 2. Potensi Tumbuh Maksimum (\%)

\begin{tabular}{lllll}
\hline \multirow{2}{*}{ Varietas Jagung } & \multicolumn{3}{c}{ Ketinggian Tempat } & \multirow{2}{*}{ Rerata } \\
\cline { 2 - 4 } & T1 (Eban) & T2 (Wini) & T3 (Mamsena) & \\
\hline A1 (Lokal Kecil) & $85,0 \mathrm{a}$ & $100 \mathrm{a}$ & $16,0 \mathrm{bc}$ & $67.1 \mathrm{a}$ \\
A2 (Lokal Besar) & $96.0 \mathrm{a}$ & $93.3 \mathrm{a}$ & $24.0 \mathrm{bc}$ & $71.1 \mathrm{a}$ \\
A3 (Hibrida) & $9.3 \mathrm{c}$ & $36.0 \mathrm{~b}$ & $13.3 \mathrm{c}$ & $19.5 \mathrm{~b}$ \\
\hline Rerata & $63.5 \mathrm{~b}$ & $76.4 \mathrm{a}$ & $17.7 \mathrm{c}$ & $(+)$
\end{tabular}

Keterangan: Angka pada baris dan kolom diikuti dengan huruf yang sama tidak berbeda nyata menurut uji Duncan (HSD) $\propto 5 \%$. (+) = terjadi interaksi antar faktor.

\subsection{Jenis Patogen dan Kejadian Penyakit}

a. Genus Aspergilus sp

Berdasarkan hasil identifikasi secara mikroskopis, terdapat beberapa jenis cendawan yang menginfeksi benih jagung antara lain: Aspergillus, sp1, Aspergillus sp2, Aspetgillus sp3 Cendawan Aspergillus sp memiliki ciri-ciri warna koloni hitam kemerah-merahan, dengan tepian rata, hifa bersepta, hyaline dan lebar. Konidiofornya tegak, panjang dan terbentuk secara bebas

Cendawan Aspergillus Sp adalah salah satu jenis cendawan gudang yang banyak menginfeksi benih pada waktu penyimpanan (Justice \& Bass, 2002). Salah satu penyebab kerusakan bahan pangan, khususnya biji-bijian adalah kontaminasi cendawan selama penyimpanan (Handajani \& Purwoko, 2008). Fungi Aspergillus pada biji-bijian yang disimpan dapat mengakibatkan penurunan daya kecambah bahan, perubahan warna bahan, kenaikan suhu dan kelembapan di dalam bahan, perubahan susunan kimia di dalam bahan dan produksi dan akumulasi mikotoksin di dalam bahan (Sutjiati \& Saenong, 2002). Cendawan merupakan salah satu penyebab utama dari kerusakan benih Cendawan dapat berupa patogen atau saprofit, diantaranya adalah cendawan Fusarium sp, dapat bertahan pada benih dalam kondisi dingin atau kering.
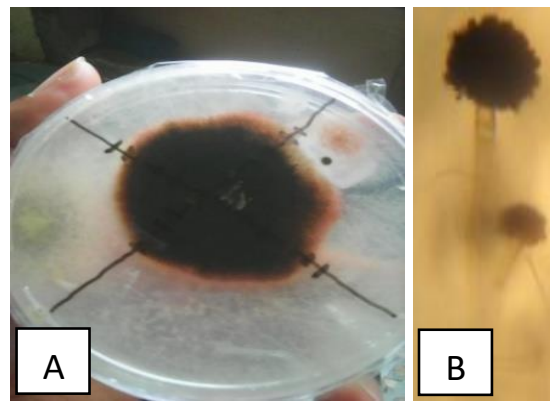

Gambar 1. Bentuk koloni Aspergillus sp (A) kondia dan koidiofor (B)

Hasil sidik ragam (Anova) menunjukkan bahwa tidak terjadi interaksi antara perlakuan pada pengamatan cendawan aspergilus sp1 (warna putih). Cendawan ini memiliki tingkat serangan paling tinggi pada varietas jagung lokal kecil $(7,78)$ dan ketinggian tempat (Wini)7,67\% berbeda nyata dengan perlakuan lainnya. sedangkan pada cendawan Aspergillus Sp2 terjadi interaksi antara ketinggian tempat dan jenis varietas.

Tabel 3. Kejadian Penyakit.

\begin{tabular}{|c|c|c|c|c|c|}
\hline \multirow[b]{2}{*}{ Cendawan } & \multirow[b]{2}{*}{ Varietas Jagung } & \multicolumn{3}{|c|}{ Ketinggian Tempat } & \multirow[b]{2}{*}{ Rerata } \\
\hline & & $\begin{array}{c}\mathrm{T} 1 \\
\text { (Eban) }\end{array}$ & $\begin{array}{c}\mathrm{T} 2 \\
\text { (Wini) }\end{array}$ & $\begin{array}{c}\mathrm{T} 3 \\
\text { (Mamsena) }\end{array}$ & \\
\hline \multirow{4}{*}{ Aspergillus sp 1} & Lokal Kecil & 9,00 & 6,67 & 7,67 & $7,78 \mathrm{a}$ \\
\hline & Lokal Besar & 2,33 & 8,33 & 10,00 & $6,89 \mathrm{a}$ \\
\hline & Hibrida & 0 & 8,00 & 0 & $2,67 \mathrm{~b}$ \\
\hline & Rerata & $3,78 \mathrm{~b}$ & $7,67 \mathrm{a}$ & $5,89 \mathrm{ab}$ & $(+)$ \\
\hline \multirow{4}{*}{ Aspergillus.sp 2} & Lokal Kecil & 0,33 & 0 & 0 & $0,11 \mathrm{a}$ \\
\hline & Lokal Besar & 0,33 & 0,33 & 0 & $0,22 \mathrm{a}$ \\
\hline & Hibrida & 0 & 0 & 0 & $0,00 \mathrm{~b}$ \\
\hline & Rerata & $0,22 \mathrm{a}$ & $0,11 \mathrm{a}$ & $0 \mathrm{a}$ & $(-)$ \\
\hline \multirow{4}{*}{ Aspergillus.sp 3} & Lokal Kecil & 2,33 & 0 & 2,33 & $1,56 \mathrm{~b}$ \\
\hline & Lokal Besar & 0 & 0,67 & 0 & $0,22 \mathrm{~b}$ \\
\hline & Hibrida & 1,33 & 2,00 & 8,67 & $4,00 \mathrm{a}$ \\
\hline & Rerata & $1,22 \mathrm{~b}$ & $0,89 \mathrm{~b}$ & $3,67 \mathrm{a}$ & $(+)$ \\
\hline \multirow{4}{*}{ Fusarium sp } & Lokal Kecil & 0 & 3,33 & 0 & $1,11 \mathrm{a}$ \\
\hline & Lokal Besar & 7,33 & 0,67 & 0 & $2,67 \mathrm{a}$ \\
\hline & Hibrida & 8,67 & 0 & 1,33 & $3,33 \mathrm{a}$ \\
\hline & Rerata & $5,33 \mathrm{a}$ & $1,33 \mathrm{~b}$ & $0,44 \mathrm{~b}$ & $(-)$ \\
\hline
\end{tabular}

Keterangan: Angka pada baris dan kolom diikuti dengan huruf yang sama tidak berbeda nyata menurut uji Duncan (HSD) $\alpha 5 \% .(+)=$ terjadi interaksi antar faktor. $(-)=$ tidak terjadi interaksi antar faktor.
Serangan tertinggi pada varietas lokal besar dan berbeda nyata dengan varietas hibrida yang tidak terinfeksi. pathogen ini tidak menginfeksi benih jagung di Mamsena, tetapi menginfeksi benih jagung di Eban dengan persentase tertinggi. Infeksi aspergillus Sp3 pada benih jagung tidak terjadi interaksi antara perlakuan. Serangan Aspergillus Sp3 tertinggi pada varietas hibrida dengan persentase 4,00\% dan ketinggian tempat 400-800 mdpl (Mamsena) 3,67\% berbeda nyata dengan perlakuan lainnya.

\section{b. Genus Fusarium sp .}

Ciri-ciri morfologi Cenadawan Fusarium sp yaitu warna koloni berwarna hitam kemerah-merahan struktur tubuh berupa miselium bercabang, hialin dan bersekat (septat). Ciri konidia berbentuk oval, terdiri dari 3 sampai 4 sekat, berwarna hialin, bagian tengahnya membesar, kedua ujung konidia meruncing seperti bulan sabit (Gambar 2.). Hal ini sesuai dengan hasil penelitian Nugraheni (2010) bahwa cendawan Fusarium sp. memiliki makrokonidia berbentuk melengkung, panjang dengan ujung yang mengecil dan mempunyai satu atau tiga buah sekat

Cendawan Fusarium Sp. dapat mengakibatkan warna benih berubah, perkecambahan terhambat, dan dapat menyebabkan penyakit di persemaian atau pada tanaman dewasa di lapangan. Selama biji atau benih dalam penyimpanan, aktivitas cendawan tersebut terhenti (istirahat) karena syarat untuk pertumbuhannya tidak terpenuhi (Rahayu, 1999). Cendawan Fusarium sp adalah salah satu jenis cendawan gudang yang banyak menginfeksi benih pada waktu penyimpanan (Justice \& Bass, 2002).

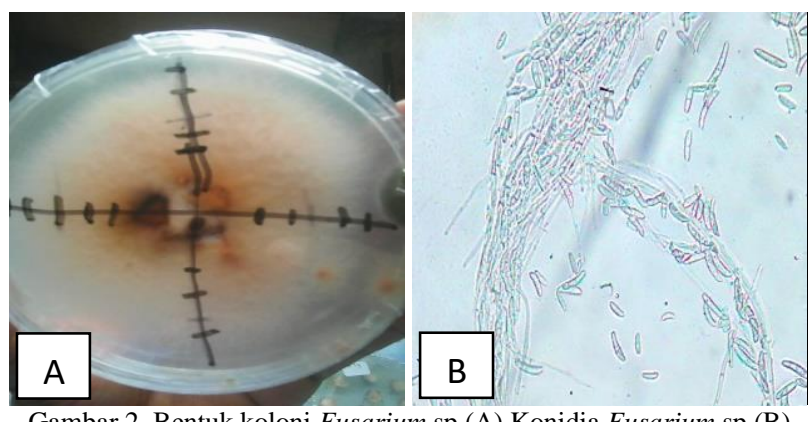

Gambar 2. Bentuk koloni Fusarium sp (A) Konidia Fusarium sp (B)

Hasil sidik ragam (Anova) menunjukkan bahwa tidak terjadi interaksi antara perlakuan pada pengamatan cendawan Aspergilus sp1 (warna putih). Cendawan ini memiliki tingkat serangan paling tinggi pada varietas jagung lokal kecil $(7,78)$ dan ketinggian tempat (Wini) $7,67 \%$ berbeda nyata dengan perlakuan lainnya. sedangkan pada cendawan Aspergillus sp2 terjadi interaksi antara ketinggian tempat dan jenis varietas. Serangan tertinggi pada varietas lokal besar dan berbeda nyata dengan varietas hibrida yang tidak terinfeksi. pathogen ini tidak menginfeksi benih jagung di Mamsena, tetapi menginfeksi benih jagung di Eban dengan persentase tertinggi. Infeksi Aspergillus sp3 pada benih jagung tidak terjadi interaksi antara perlakuan. Serangan Aspergillus sp3 tertinggi pada varietas hibrida dengan persentase 4,00\% dan ketinggian tempat 400-800 mdpl (Mamsena) 3,67\% berbeda nyata dengan perlakuan lainnya.

\section{Simpulan}

Cendawan patogen yang menginfeksi benih jagung di TTU adalah Aspergillus sp dan Fusarium sp. Aspergilus sp1 menginfeksi benih jagung lokal kecil 9\% di Eban lebih tinggi dari yang lain,, Fusarium sp menginfeksi benih jagung hibrida 8,67\% di Eban lebih tinggi intensitas serang dari yang lainnya. Pengujian daya kecambah benih pada ketiga varietas berkisar antara $16,44 \%$ $26,00 \%$.

\section{Pustaka}

Agarwal, V.K. and Sinclair, J.B. 1987. Seedborne pathogens, p. 17-76. In Principles of Seed Pathology Vol I. Florida: CRC Press, Inc.

Gomez, K.A. \& Gomez, A.A. 1984. Statistical Procedures for Agricultural Research. New York: John Wiley \& Sons.

Leki, W., Lelang, M.A. \& Taolin, R.I. 2016. Pengaruh Takaran Pupuk Kandang Sapi Terhadap Pertumbuhan dan Hasil Jagung (Zea mays, L.) yang Ditumpangsarikan dengan Kedelai (Glysine max,(L.) Merril). Savana Cendana, 1(01): 17-23

Handajani, N.S. dan T. Purwoko. 2008. Aktivitas ekstrak rimpang lengkuas (Alpinia galanga) terhadap pertumbuhan jamur Aspergillus spp. penghasil aflatoksin dan Fusarium moniliforme. BIODIVERSITAS. 9(5): 161-164.

Justice, O.L. L.N. Bass. 2002. Prinsip dan Praktek Penyimpanan Benih. Jakarta: Raja Grafindo Persada.

Mathur, S.B. \& Kongsdal, O. 2003. Common laboratory seed health testing methods for detecting fungi. Bassersdorf, Switzerland: International Seed Testing Association.

Muis, A, S. Pakki dan A.H. Talanca. 2002. Inventarisasi dan identifikasi cendawan yang menyerang biji jagung di Sulawesi selatan. Hasil penelitian Hama dan Penyakit, Balitsereal, Maeos. 
Nugraheni, E.S. 2010. Karakterisasi Biologi Isolat-Isolat Fusarium sp. pada Tanaman Cabai Merah (Capsicum aпnиum L.) Asal Boyolali. Skripsi. Surakarta: Jurusan Agronomi Fakultas Pertanian, Universitas Sebelas Maret.

Purwono dan R. Hartono. 2008. Bertanam Jagung Unggul. Jakarta: Penebar Swadaya.

Rahayu, S. 1999. Penyakit Tanaman Hutan di Indonesia (Gejala, Penyebab, dan Teknik pengendaliannya). Yogyakarta: Penerbit Kanisius.

Sadjad, S. 1994. Kuantifikasi Metabolisme Benih. Jakarta: PT. Gramedia Widiasarana Indonesia.

Schutless, F., K.F. Cardwell, and S. Gounou. 2002. The effect of endhophytic Fusarium verticilliodes on investasion of two maize variety by lepidoptera stemborer and coleoptera grain feeders. The American Phytophatologycal Society.

Sutjiati, M. dan M.S. Saenong. 2002. Infeksi cendawan Aspergillus sp. pada beberapa varietas/galur jagung hibrida umur dalam. Proseding Seminar Ilmiah dan Pertemuan Tahunan PEI, PFI dan HPTI XV Sul-Sel. Maros, 29 Oktober 2002

Wonkay, R.E. \& Taolin, R.I.C.O. 2016. Pengaruh Model Penyimpanan Benih dan Jenis Pupuk Kandang terhadap Pertumbuhan dan Hasil Jagung (Zea mays L.). Savana Cendana, 1(04): 128-132. 